\begin{abstract}
Iranica
Abstracta Iranica Revue bibliographique pour le domaine irano-aryen

Volume 32-33 | 2013

Comptes rendus des publications de 2009-2010
\end{abstract}

\title{
Armen Tokatlian. Kalantars, Les seigneurs arméniens dans la Perse safavide
}

\section{Aurélie Chabrier}

\section{(2) OpenEdition}

1 Journals

\section{Édition électronique}

URL : http://journals.openedition.org/abstractairanica/40692

DOI : 10.4000/abstractairanica.40692

ISSN : 1961-960X

Éditeur :

CNRS (UMR 7528 Mondes iraniens et indiens), Éditions de l'IFRI

\section{Édition imprimée}

Date de publication : 1 décembre 2013

ISSN : 0240-8910

\section{Référence électronique}

Aurélie Chabrier, "Armen Tokatlian. Kalantars, Les seigneurs arméniens dans la Perse safavide», Abstracta Iranica [En ligne], Volume 32-33 | 2013, document 262, mis en ligne le 01 juillet 2016, consulté le 26 septembre 2020. URL : http://journals.openedition.org/abstractairanica/40692 ; DOI : https://doi.org/10.4000/abstractairanica.40692

Ce document a été généré automatiquement le 26 septembre 2020.

Tous droits réservés 


\title{
Armen Tokatlian. Kalantars, Les seigneurs arméniens dans la Perse safavide
}

\author{
Aurélie Chabrier
}

\section{RÉFÉRENCE}

Armen Tokatlian. Kalantars, Les seigneurs arméniens dans la Perse safavide. Paris, Geuthner, 2009, 95 p.

1 Spécialiste de l'art oriental, Armen Tokatlian propose une synthèse abondamment illustrée sur la place de la communauté arménienne au sein de l'État safavide et sur son influence dans l'art pictural iranien. Après un bref historique des rapports entre les Safavides et les Arméniens depuis le début du XVI ${ }^{e}$ s. jusqu'au règne de Šāh 'Abbās (r. 1587-1629), l'A. s'intéresse plus particulièrement aux Arméniens de la Nouvelle Joulfa - installés à Ispahan depuis la déportation de 1604-1605 - dont il entreprend d'analyser les liens avec le pouvoir («La constance des Gholams» / «La préexcellence des Khojas »). Il traite également de la difficile acclimatation cultuelle des Arméniens dans l'Iran safavide («Mésententes confessionnelles»). Difficultés qui ont des répercussions sur l'art et l'architecture des églises arméniennes. Cela peut néanmoins donner lieu à des développements inattendus et à des créations originales, comme l'A. nous en fait la démonstration dans ses derniers chapitres sur "Une reconstruction visuelle novatrice » et les « Convergences esthétiques ».

2 Au terme de cette lecture, on s'étonnera de trouver la définition - très partielle - du titre, Kalantar, en note de bas-de-page, à la fin de l'ouvrage, sans référence à l'article de A.K.B Lambton ("The Office of Kalântar under the Safawids and Afshars », Mélanges Massé, Université de Téhéran, 1963, p. 206-218). Il convient de noter la confusion qui demeure entre kalāntar (terme de l'administration civile utilisé pour désigner le représentant officiel d'une communauté, qui sert de relais avec les autorités; un 
" maire ", voir J. Calmard) et khwojâ ( $H^{v}$ ojā) (qui fait plus proprement référence aux «seigneurs » arméniens, voir K. Kévonian et M. Aghassian, «Le commerce arménien dans l'Océan Indien au 17e et 18e siècles ", in : Lombard et Aubin (dirs.), Marchands et hommes d'affaires asiatiques dans l'Océan Indien, Paris, éd. EHESS, 1988). En outre, l'A. ne prend pas en compte une partie importante de la bibliographie sur le sujet, notamment les travaux de R. Gulbenkian et de W. Floor (voir par exemple W. Floor et P. Clawson "Safavid Iran's Search for Silver and Gold ", International Jounal of Middle East Studies, 32, 2000, p. 345-368); ce qui ne lui permet guère de nuancer le rôle des Arméniens de la Nouvelle Joulfa au XVII ${ }^{\mathrm{e}}$ siècle. On regrettera également les nombreuses coquilles qui parsèment le texte.

\section{AUTEURS}

\section{AURÉLIE CHABRIER}

Paris 